\title{
Understanding the Effect of Climate Change on Temperature and Precipitation in Sirmaur District of Himachal Pradesh
}

\author{
Reena Joshi ${ }^{1^{*}}$ and K. S. Verma ${ }^{2}$ \\ ${ }^{1}$ College of Forestry, V.C.S.G. University of Horticulture and Forestry, Ranichauri-Tehri \\ Garhwal- 249 199, Uttarakhand, India \\ ${ }^{2}$ Y. S. Parmar University of Horticulture and Forestry, Nauni-173 230, Solan, Himanchal \\ Pradesh, India \\ *Corresponding author
}

\section{Keywords}

Climate change, Temperature, Rainfall, Seasons

Article Info

Accepted: 10 September 2020 Available Online: 10 October 2020

\section{A B S T R A C T}

In this study, analyzed the long-term changes in temperature and precipitation in the Sirmaur district of Himachal Pradesh to understand the climate change impact on regional weather. Current (2001-2010) and past (1984-2000) climatic scenario revealed that the region has experienced increase in maximum and minimum temperature. Temperatures in different seasons of the year viz. winter, spring, summer and autumn have shown increasing trends, whereas the precipitation in the form of rainfall decreased except in autumn season.

\section{Introduction}

The changing climate and warming of the atmosphere have a large impact on physical weather elements of a region or a country. Variations in the frequency and intensity of extreme weather events, such as floods, droughts, cyclones and western disturbances, and the occurrence of weather events such as heat and cold waves over India allow scientific communities to examine if parameters associated with these events can be considered as evidence for climate change.
Long-term trends in the maximum, minimum and mean temperatures over the north-western Himalaya during the 20th century (Bhutiyani et al., 2007) suggest a significant rise in air temperature in the north-western Himalaya, with winter warming occurring at a faster rate. The study also shows that significant warming started in the late 1960s, with the highest rate of increase between 1990 and 2009. Dimri and Ganju (2007) simulated wintertime temperature and precipitation over the western Himalaya. They used a regional climate model and found that temperature is 
underestimated and precipitation is overestimated in the Himalaya. Some past studies relating to changes in rainfall over India have concluded that there is no clear trend of increase or decrease in average annual rainfall over the country (Mooley and Parthasarathy, 1984; Sarker and Thapliyal, 1988; Thapliyal and Kulshrestha, 1991; Lal, 2001). Though no trend in the monsoon rainfall in India is found over a long period of time, particularly on the all-India scale, pockets of significant long-term rainfall changes have been identified (Koteswaram and Alvi, 1969; Jagannathan and Parthasarathy, 1973; Raghavendra, 1974; Chaudhary and Abhyankar, 1979; Kumar et al., 2005; Dash et al., 2007; Kumar and Jain, 2009).

Several observational studies show significant temperature and precipitation changes in India over the long term. Studies by (Khan et al., 2000; Shrestha et al., 2000; Mirza, 2002; Lal, 2003; Min et al., 2003; Dash et al., 2007) show that, in general, the frequency of more intense rainfall events in many parts of Asia has increased, while the number of rainy days and total annual amount of precipitation has decreased. Goswami et al., (2006) used daily rainfall data to show the significant rising trends in the frequency and magnitude of extreme rain events, and a significant decreasing trend in the frequency of moderate events over central India during the monsoon seasons from 1951 to 2000. Shekhar et al., (2010) revealed that different ranges of the western Himalaya shows significant variations in temperature and snowfall trends in the past few decades. Kothawale and Rupa Kumar (2005) reported that the all India mean annual temperature increased by $0.58{ }^{\circ} \mathrm{C}$ during 1901-2003. This increase is consistent with the expected effects from global warming. The temperature and precipitation trends over north and south India for different phases of the monsoon were investigated by
Dash and Hunt (2007) and Dash et al., (2007). They found large differences in trends in minimum temperature and cloud cover between north and south India and asymmetry in increasing temperature trends between different seasons. They also found a reduction in the summer monsoon (June-September) rainfall over India, and suggested this reduction can be explained by both climate change and the mesoscale effects of the mountains on monsoon flow.

The changing trends of temperature and precipitation over the western Himalaya were examined by Dimri and Kumar (2008), who calculated the number of warm and cold events during winter (December-February) for 1975-2006. They found a trend of increasing temperature and decreasing precipitation at some specific locations. Observational studies by Kripalani et al., (2003) revealed that the area of spring snow cover across the western Himalaya has been declining and the snow has been melting faster from winter to spring since 1993, which may be due to global warming.

The western Himalayas are particularly prone to severe weather, due to the movement of western disturbances during the winter months. The synoptic aspects of western disturbances have been discussed by many authors (Pisharoty and Desai, 1956; Rao and Srinivasan, 1969; Kalsi, 1980; Azadi et al., 2002; Hatwar et al., 2001; Dimri, 2008) and are the primary sources of precipitation over the western Himalaya during winter, where the number of snowfall days and the amount of snowfall depend on the number of occurrences and the intensity of the western disturbances. In an observational study, Das et al., (2002) found that western disturbances in the Himalaya activate monsoons in certain areas of north-western India. They also studied trends in the annual pre-monsoon (March-May) frequency of western 
disturbances and the onset date of monsoon over north India for the period 1971-2000 and found that frequency of May western disturbances has significantly decreased over recent years. So, that to finding the impact of climate change on regional weather, the study was carried out in Sirmaur district during 2009-10.

\section{Materials and Methods}

The present study was carried in Sirmaur district which is in the south eastern corner of Himachal Pradesh (Fig. 1). The district lies in the Shivalik hills between $30^{\circ} 22^{\prime} 30^{\prime \prime}$ and $31^{\circ}$ 01' 20" North Longitude and between $77^{\circ} 01^{\prime}$ $12^{\prime \prime}$ and $77^{\circ}$ 49' 40" East Longitude spread over an area of $2825 \mathrm{~km}^{2}$. The elevation of hills varies from $900 \mathrm{~m}$ to $3650 \mathrm{~m}$. The district has varied climatic zones ranging from humid, subtropical, humid-temperate to moist-temperate zones. The mean annual temperature of the district ranges between $3.5^{\circ} \mathrm{C}$ to $38^{\circ} \mathrm{C}$ and the average annual rainfall is $104 \mathrm{~cm}$, a major part of which is received during monsoons. Recent long-term monthly meteorological data for temperature and precipitation for the period 1984- 2010 was obtained from Meteorological Department of Dr. Y.S. Parmar University of Horticulture and Forestry, Solan (H.P.) spanning over the study region.

Regional climate attributes i.e. Maximum temperature $\left(\mathrm{T}_{\max }\right)$, minimum temperature $\left(\mathrm{T}_{\min }\right)$ and average temperature $\left(\mathrm{T}_{\mathrm{av}}\right)$ as well as Mean rainfall and Total rainfall at monthly and season wise i.e. winter (December, January, February), spring (March, April, May), summer (June, July, August) and autumn (September, October, November)for three different periods 1991-2000 (P1) and 2001-10 (P2) and 1984-1990 (BL) for the region were analyzed. The period 1984-1990 was taken as baseline (BL) for comparison.

\section{Results and Discussion}

In the following paragraphs, first we have discussed changes in maximum temperature, minimum temperature and average temperature followed by precipitation. These changes have been analysed both at seasonal and monthly basis and compared with base line period. The results obtained are described as below:

\section{Seasonal variation trends in Temperature} $\left({ }^{\circ} \mathbf{C}\right)$

Past and present climate trends and variations in temperature were analyzed season wise. Maximum temperature, minimum temperature and average temperature for three different periods $\mathrm{P} 1$ and $\mathrm{P} 2$ and $\mathrm{BL}$ for the region are given in Table $1 . \mathrm{T}_{\max }$ during the period 1991-2000 and 2001-10 compared over the baseline has shown increase in every season. Winter temperature showed highest increase over the baseline. It was increased by $0.95{ }^{\circ} \mathrm{C}$ during $1991-2000$ and $2.96{ }^{\circ} \mathrm{C}$ during 2001-10. During spring, $\mathrm{T}_{\max }$ rose by $0.25{ }^{\circ} \mathrm{C}$ over the baseline during 1991-2000 and $2.12^{\circ} \mathrm{C}$ during $2001-10$. An increase of $0.48^{\circ} \mathrm{C}$ during 1991-2000 and $1.49^{\circ} \mathrm{C}$ during 20012010 in summer over baseline occurred. In autumn, it increased by $0.56{ }^{\circ} \mathrm{C}$ during 1991 2000 and $1.51^{\circ} \mathrm{C}$ during $2001-2010$ over the baseline. An increase of $0.12{ }^{\circ} \mathrm{C}$ was in $\mathrm{T}_{\text {min }}$ in winter season during 1991-2000 period and $0.27{ }^{\circ} \mathrm{C}$ during the period of 2001-10 over baseline was observed. In spring, $\mathrm{T}_{\min }$ was decreased by $0.58{ }^{\circ} \mathrm{C}$ during 1990-2000 period, while it increased by $0.31{ }^{\circ} \mathrm{C}$ during 2000-10. During summer, $\mathrm{T}_{\min }$ rose by $0.83^{\circ} \mathrm{C}$ during 1991-2000 and $0.80^{\circ} \mathrm{C}$ during 2001-10 over the baseline and was highest among all the seasons. In autumn $\mathrm{T}_{\min }$ increase was of $0.38^{\circ} \mathrm{C}$ during $1991-2000$ and $0.11{ }^{\circ} \mathrm{C}$ during the period of 2001-10. The average temperature $\left(\mathrm{T}_{\mathrm{av}}\right)$ during the period 19912000 and 2000-10 increased by $0.50{ }^{\circ} \mathrm{C}$ and 
$1.58{ }^{\circ} \mathrm{C}$, respectively over baseline in winter. It decreased by $0.19{ }^{\circ} \mathrm{C}$ during $1991-2000$ and increased by $1.19{ }^{\circ} \mathrm{C}$ during 2001-10 in spring. In summers of 1991-2000 an increase of $0.66^{\circ} \mathrm{C}$ whereas of $1.18^{\circ} \mathrm{C}$ during 2001 2010 over baseline occurred. An increase of $0.52{ }^{\circ} \mathrm{C}$ during $1991-2000$ and $0.86^{\circ} \mathrm{C}$ during 2001-2010 in autumn over the baseline was observed.

\section{Monthly variation trends in Temperature $\left({ }^{\circ} \mathrm{C}\right)$}

Month wise variation in past and present temperatures: $\mathrm{T}_{\max }, \mathrm{T}_{\min }$ and $\mathrm{T}_{\mathrm{av}}$ have been presented in Table $2 . \mathrm{T}_{\max }$ increased in all the months during 1991-2000 and 2001-2010 except April and September of 1991-2000 period, where it decreased over baseline period. During 1991-2000 $\mathrm{T}_{\max }$ increased from January to March, then it decreased in April, again it increased from May to August. In the month of September, it decreased and again it increased in October, November and December. During 2001-10 $\mathrm{T}_{\max }$ increased from January to December over the baseline period. Increase in $T_{\max }$ in December (1.60 $\left.{ }^{\circ} \mathrm{C}\right)$ of P1 and February $\left(3.24{ }^{\circ} \mathrm{C}\right)$ of P2 was observed maximum in all the months over BL. $\mathrm{T}_{\min }$ showed an increasing as well as decreasing trend in the period of 1991-2000 and 2001-2010 over the baseline period. An increase in $\mathrm{T}_{\min }$ from January to March, then it decreased from April to June, and again increased for July, August, September and November and decreased for October and December during 1991-2000 period over baseline. During 2001-2010 period, $\mathrm{T}_{\text {min }}$ increased from January to April and decreased for May, October and December respectively and again increased from June to September and November over the baseline. Maximum increase in $T_{\min }$ was observed in the month of August and it was $1.69{ }^{\circ} \mathrm{C}$ for P1and $1.23^{\circ} \mathrm{C}$ for $\mathrm{P} 2$ over BL. Average monthly Temperature increased in all the months in the period of 1991-2000 and 20012010 except April of 1991-2000 period, where it decreased by $0.74{ }^{\circ}$ Cover the baseline period. During the period of 19912000, $\mathrm{T}_{\mathrm{av}}$ increased from January to March, then it decreased in April, again it increased from May to December over the baseline, whereas maximum increase was in August $\left(0.97{ }^{\circ} \mathrm{C}\right)$. In the period of 2001-10, $\mathrm{T}_{\mathrm{av}}$ increased from January to December over the baseline, while maximum increase in February $\left(1.96{ }^{\circ} \mathrm{C}\right)$ was observed.

The findings are in line with Kothawale and Rupa Kumar (2005), who reported that India mean annual temperature increased by 0.58 ${ }^{\circ} \mathrm{C}$ during 1901-2003. Long-term trends in the maximum, minimum and mean temperatures over the northwestern Himalaya during the 20th century (Bhutiyani et al., 2007) suggest a significant rise in air temperature in the north-western Himalaya, with winter warming occurring at a faster rate. The study also shows that significant warming started in the late 1960s, with the highest rate of increase between 1990 and 2009. Dash and Hunt (2007) and Dash et al., (2007) found large differences in trends in minimum temperature between north and south India and asymmetry in increasing temperature trends between different seasons. Dimri and Kumar (2008) and Shekhar et al., (2010) found increasing trend of temperature over the western Himalaya in the past few decades. Similar findings recorded by Shafiq et al., (2018) that steeper increase in annual mean maximum temperature than annual mean minimum temperature during 19802014 in Kashmir valley.

\section{Seasonal variation trends in Precipitation (mm)}

Total rainfall in the period of 1991-2000 decreased over the years by $25.87 \mathrm{~mm}$ in spring and $86.90 \mathrm{~mm}$ in summer, while it 
increased in winter by $21.90 \mathrm{~mm}$ and 23.86 $\mathrm{mm}$ in autumn over the baseline period. During 2001-10 period the total rainfall decreased in winter by $21.88 \mathrm{~mm}$, spring $(56.28 \mathrm{~mm})$ and summer $(211.64 \mathrm{~mm})$, whereas in autumn it increased by $56.26 \mathrm{~mm}$ over the baseline. Maximum decrease was recorded in summer rainfall during $\mathrm{P} 1$ as well as P2 (Table 3).

\section{Monthly variation trends in Precipitation (mm)}

Mean monthly rainfall for the 1991-2000 and 2001-10 period over the baseline showed increasing as well as decreasing trend. In the period of 1991-2000 mean rainfall increased in months of January, February, April, June, September and October and it decreased for the months March, May, July, August, November and December over the baseline period. During 2001-10 mean rainfall decrease was more over baseline. It decreased in March, May to August, and October to December. Mean rainfall increased in the months of January, February, April and September over baseline. Maximum reduction in mean rainfall was recorded in July by 52.47 $\mathrm{mm}$ during 1991-2000 and $111.42 \mathrm{~mm}$ in 2001-10 over the baseline (Table 4). An increase in total monthly rainfall during 19912000 over baseline was observed except in December, which later during 2001-10 showed considerable decrease.

Table.1 Seasonal variation trends in mean maximum $\left({ }^{\circ} \mathrm{C}\right)$, mean minimum $\left({ }^{\circ} \mathrm{C}\right)$ and average temperature $\left({ }^{\circ} \mathrm{C}\right)$ for three different periods

\begin{tabular}{|c|c|c|c|c|}
\hline \multirow[t]{2}{*}{ Period } & \multicolumn{4}{|c|}{ Season } \\
\hline & Winter & Spring & Summer & Autumn \\
\hline \multicolumn{5}{|l|}{ Mean Max. } \\
\hline 1984-90 (BL) & 17.55 & 26.82 & 28.52 & 24.98 \\
\hline $1991-2000$ (P1) & 18.50 & 27.07 & 29.00 & 25.54 \\
\hline 2001-10 (P2) & 20.51 & 28.94 & 30.01 & 26.49 \\
\hline \multicolumn{5}{|c|}{ Increase/decrease over baseline } \\
\hline P1 & 0.95 & 0.25 & 0.48 & 0.56 \\
\hline $\mathbf{P 2}$ & 2.96 & 2.12 & 1.49 & 1.51 \\
\hline \multicolumn{5}{|l|}{ Mean Min. } \\
\hline 1984-90 (BL) & 3.02 & 12.39 & 18.78 & 10.74 \\
\hline $1991-2000(\mathrm{P} 1)$ & 3.14 & 11.81 & 19.61 & 11.12 \\
\hline 2001-10 (P2) & 3.29 & 12.70 & 19.58 & 10.85 \\
\hline \multicolumn{5}{|c|}{ Increase/decrease over baseline } \\
\hline P1 & 0.12 & -0.58 & 0.83 & 0.38 \\
\hline $\mathbf{P 2}$ & 0.27 & 0.31 & 0.8 & 0.11 \\
\hline \multicolumn{5}{|l|}{ Average } \\
\hline 1984-90 (BL) & 10.32 & 19.63 & 23.64 & 17.81 \\
\hline 1991-2000 (P1) & 10.82 & 19.44 & 24.30 & 18.33 \\
\hline 2001-10 (P2) & 11.90 & 20.82 & 24.82 & 18.67 \\
\hline \multicolumn{5}{|c|}{ Increase/decrease over baseline } \\
\hline P1 & 0.5 & -0.19 & 0.66 & 0.52 \\
\hline P2 & 1.58 & 1.19 & 1.18 & 0.86 \\
\hline
\end{tabular}


Table. 2 Monthly variation trends in mean maximum $\left({ }^{\circ} \mathrm{C}\right)$, mean minimum $\left({ }^{\circ} \mathrm{C}\right)$ and average temperature $\left({ }^{\circ} \mathrm{C}\right)$ for last three decades

\begin{tabular}{|c|c|c|c|c|c|c|c|c|c|c|c|c|}
\hline \multirow{2}{*}{$\begin{array}{l}\text { Time period \& } \\
\text { Temperature }\end{array}$} & \multicolumn{12}{|c|}{ Month } \\
\hline & Jan & Feb & Mar & Apr & May & Jun & Jul & Aug & Sep & Oct & Nov & Dec \\
\hline \multicolumn{13}{|l|}{ Mean Max. } \\
\hline 1984-90 (BL) & 16.36 & 17.76 & 22.21 & 27.49 & 30.77 & 30.56 & 27.61 & 27.39 & 27.57 & 25.36 & 22.00 & 18.54 \\
\hline 1991-2000 (P1) & 16.90 & 18.45 & 22.41 & 27.34 & 31.46 & 30.91 & 28.43 & 27.65 & 27.49 & 26.21 & 22.92 & 20.14 \\
\hline 2001-10 (P2) & 19.47 & 21.00 & 25.19 & 29.57 & 32.05 & 32.33 & 29.21 & 28.50 & 28.31 & 27.16 & 24.01 & 21.07 \\
\hline \multicolumn{13}{|c|}{ Increase/decrease over baseline } \\
\hline P1 & 0.54 & 0.69 & 0.2 & -0.15 & 0.69 & 0.35 & 0.82 & 0.26 & -0.08 & 0.85 & 0.92 & 1.6 \\
\hline P2 & 3.11 & 3.24 & 2.98 & 2.08 & 1.28 & 1.77 & 1.6 & 1.11 & 0.74 & 1.8 & 2.01 & 2.53 \\
\hline \multicolumn{13}{|l|}{ Mean Min. } \\
\hline 1984-90 (BL) & 1.91 & 3.84 & 7.81 & 12.91 & 16.44 & 18.70 & 19.13 & 18.51 & 16.21 & 10.56 & 5.44 & 3.30 \\
\hline 1991-2000 (P1) & 2.47 & 4.09 & 7.84 & 11.58 & 16.01 & 18.53 & 20.11 & 20.2 & 16.99 & 10.33 & 6.04 & 2.87 \\
\hline 2001-10 (P2) & 2.24 & 4.66 & 8.64 & 13.22 & 16.23 & 18.74 & 20.27 & 19.74 & 16.64 & 10.32 & 5.59 & 2.97 \\
\hline \multicolumn{13}{|c|}{ Increase/decrease over baseline } \\
\hline P1 & 0.56 & 0.25 & 0.03 & -1.33 & -0.43 & -0.17 & 0.98 & 1.69 & 0.78 & -0.23 & 0.6 & $-\mathbf{0 . 4 3}$ \\
\hline $\mathbf{P 2}$ & 0.33 & 0.82 & 0.83 & 0.31 & -0.21 & 0.04 & 1.14 & 1.23 & 0.43 & -0.24 & 0.15 & -0.33 \\
\hline \multicolumn{13}{|l|}{ Average } \\
\hline 1984-90 (BL) & 9.22 & 10.87 & 15.09 & 20.20 & 23.61 & 24.61 & 23.37 & 22.95 & 21.89 & 17.96 & 13.57 & 10.86 \\
\hline 1991-2000 (P1) & 9.69 & 11.27 & 15.13 & 19.46 & 23.73 & 24.72 & 24.26 & 23.92 & 22.24 & 18.27 & 14.48 & 11.5 \\
\hline 2001-10 (P2) & 10.86 & 12.83 & 16.91 & 21.40 & 24.14 & 25.54 & 24.74 & 24.12 & 22.48 & 18.74 & 14.80 & 12.02 \\
\hline \multicolumn{13}{|c|}{ Increase/decrease over baseline } \\
\hline P1 & 0.47 & 0.4 & 0.04 & -0.74 & 0.12 & 0.11 & $\mathbf{0 . 8 9}$ & 0.97 & 0.35 & 0.31 & 0.91 & 0.64 \\
\hline P2 & 1.64 & 1.96 & 1.82 & 1.2 & 0.53 & 0.93 & 1.37 & 1.17 & 0.59 & 0.78 & 1.23 & 1.16 \\
\hline
\end{tabular}


Table.3 Season wise periodic/decadal variations in rainfall (mm)

\begin{tabular}{|l|c|c|c|c|}
\hline \multirow{2}{*}{ Time Period } & \multicolumn{4}{c|}{ Season } \\
\cline { 2 - 5 } & Winter & Spring & Summer & Autumn \\
\hline $\mathbf{1 9 8 4 - 9 0}(\mathbf{B L})$ & 158.47 & 198.51 & 754.34 & 158.56 \\
\hline $\mathbf{1 9 9 1 - 2 0 0 0}$ (P1) & 180.37 & 172.64 & 667.44 & 182.42 \\
\hline $\mathbf{2 0 0 1 - 1 0}$ (P2) & 136.59 & 142.23 & 542.7 & 214.82 \\
\hline Increase/decrease over baseline & $\mathbf{2 1 . 9}$ & $\mathbf{- 2 5 . 8 7}$ & $\mathbf{- 8 6 . 9}$ & $\mathbf{2 3 . 8 6}$ \\
\hline P1 & $\mathbf{- 2 1 . 8 8}$ & $\mathbf{- 5 6 . 2 8}$ & $\mathbf{- 2 1 1 . 6 4}$ & $\mathbf{5 6 . 2 6}$ \\
\hline P2 & & &
\end{tabular}

Table.4 Monthly variation trends in mean rainfall $(\mathrm{mm})$ and total rainfall $(\mathrm{mm})$ for last three decades

\begin{tabular}{|c|c|c|c|c|c|c|c|c|c|c|c|c|}
\hline \multirow{2}{*}{$\begin{array}{l}\text { Time period \& } \\
\text { Precipitation }\end{array}$} & \multicolumn{12}{|c|}{ Month } \\
\hline & Jan & Feb & Mar & Apr & May & Jun & Jul & Aug & Sep & Oct & Nov & Dec \\
\hline \multicolumn{13}{|c|}{ Mean Rainfall (mm) } \\
\hline 1984-90 (BL) & 33.27 & 52.90 & 85.50 & 23.11 & 89.90 & 152.14 & 318.33 & 283.87 & 112.79 & 32.69 & 13.09 & 72.30 \\
\hline $1991-2000(P 1)$ & 81.43 & 77.27 & 64.69 & 44.72 & 63.23 & 155.75 & 265.86 & 245.83 & 136.37 & 36.28 & 9.77 & 21.67 \\
\hline 2001-10 (P2) & 40.79 & 75.35 & 61.70 & 32.98 & 47.55 & 136.72 & 206.91 & 199.07 & 172.84 & 31.25 & 10.73 & 20.45 \\
\hline \multicolumn{13}{|c|}{ Increase/decrease over baseline } \\
\hline P1 & 48.16 & 24.37 & -20.81 & 21.61 & -26.67 & 3.61 & -52.47 & -38.04 & 23.58 & 3.59 & -3.32 & -50.63 \\
\hline $\mathbf{P 2}$ & 7.52 & 22.45 & -23.8 & 9.87 & -42.35 & -15.42 & -111.42 & -84.8 & 60.05 & -1.44 & -2.36 & -51.85 \\
\hline \multicolumn{13}{|c|}{ Total Rainfall (mm) } \\
\hline 1984-90 (BL) & 232.9 & 370.3 & 598.50 & 161.80 & 629.30 & 1065.0 & 2228.3 & 1987.10 & 789.50 & 228.8 & 91.60 & 506.1 \\
\hline $1991-2000(P 1)$ & 814.25 & 772.7 & 646.9 & 447.2 & 632.3 & 1557.5 & 2658.6 & 2458.3 & 1363.7 & 362.8 & 97.7 & 216.7 \\
\hline 2001-10 (P2) & 407.9 & 753.5 & 617 & 329.8 & 475.5 & 1367.2 & 2069.1 & 1990.68 & 1728.4 & 312.5 & 107.3 & 204.5 \\
\hline \multicolumn{13}{|c|}{ Increase/decrease over baseline } \\
\hline P1 & 581.35 & 402.4 & 48.4 & 285.4 & 3.0 & 492.5 & 430.3 & 471.2 & 574.2 & 134 & 6.1 & -289.4 \\
\hline $\mathbf{P 2}$ & 175 & 383.2 & 18.5 & 168 & -153.8 & 302.2 & -159.2 & 3.58 & 938.9 & 83.7 & 15.7 & -301.6 \\
\hline
\end{tabular}


Table.5 Annual variation trends in mean rainfall $(\mathrm{mm})$ and total rainfall $(\mathrm{mm})$ for three different periods

\begin{tabular}{|l|c|c|}
\hline Time Period & Mean Annual Rainfall (mm) & Total Annual Rainfall (mm) \\
\hline $\mathbf{1 9 8 4}-1990(\mathbf{B L})$ & 1269.89 & $\mathbf{8 8 8 9 . 2 0}$ \\
\hline $\mathbf{1 9 9 0 - 2 0 0 0}(\mathbf{P 1})$ & 1202.87 & $\mathbf{1 2 0 2 8 . 6 5}$ \\
\hline $\mathbf{2 0 0 0 - 2 0 1 0}(\mathbf{P 2})$ & 1036.34 & $\mathbf{1 0 3 6 3 . 3 8}$ \\
\hline Increase/decrease over baseline & & \\
\hline P1 & $\mathbf{- 6 7 . 0 2}$ & $\mathbf{3 1 3 9 . 4 5}$ \\
\hline P2 & $\mathbf{- 2 3 3 . 5 5}$ & $\mathbf{1 4 7 4 . 1 8}$ \\
\hline
\end{tabular}

Fig.1 A map of Himachal Pradesh showing location of the study site

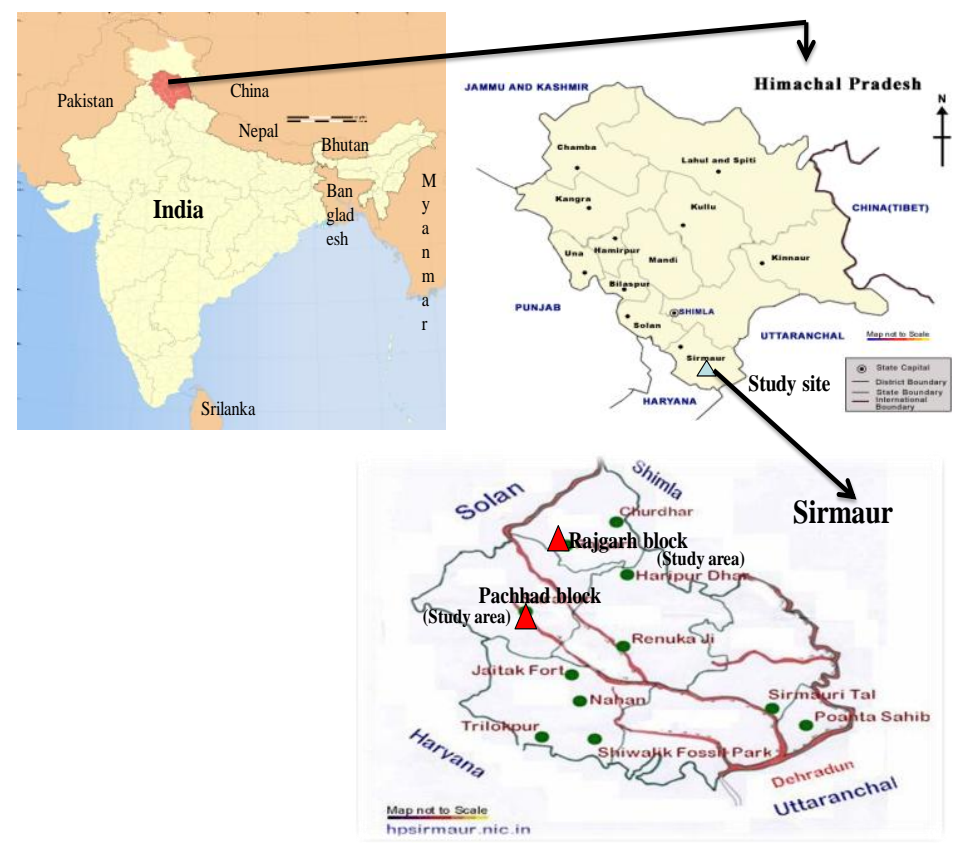

In period of 1991-2000 total rainfall increased from January to November, while decreased in December by $289.40 \mathrm{~mm}$ over baseline. Maximum increase in total rainfall was recorded in January $(581.35 \mathrm{~mm})$ followed by September $(574.20 \mathrm{~mm})$ in 1991-2000 over baseline. During 2001-10 total rainfall increased from January to April, June and August to November. In the months of May, July and December it reduced over baseline. Maximum increase in total rainfall was recorded in September $(938.9 \mathrm{~mm})$ while maximum reduction was in December (301.6 $\mathrm{mm}$ ) in 2001-10 over baseline (Table 4).

Mean annual and total annual rainfall (mm)

Mean annual and total annual rainfall were recorded and analyzed for the similar period of time (Table 5). Mean annual rainfall followed a declining trend and decreased by $67.02 \mathrm{~mm}$ in1991-2000, while by $233.55 \mathrm{~mm}$ in 2001-10 over the baseline. The total annual rainfall for 1991-2000 as well as 2001-10 increased by $3139.45 \mathrm{~mm}$ and $1474.18 \mathrm{~mm}$ 
respectively, over baseline period but total annual rainfall during $\mathrm{P} 2$ followed declining trend over P1.

Studies by (Khan et al., 2000; Shrestha et al., 2000; Mirza, 2002; Lal, 2003; Min et al., 2003; Dash et al., 2007) showed that, in general, the frequency of more intense rainfall events in many parts of Asia has increased, while the number of rainy days and total annual amount of precipitation has decreased. Some past studies relating to changes in rainfall over India have concluded that there is no clear trend of increase or decrease in average annual rainfall over the country (Mooley and Parthasarathy, 1984; Sarker and Thapliyal, 1988; Thapliyal and Kulshrestha, 1991; Lal, 2001). Kumar et al., (2010) reported that annual and monsoon rainfall decreased, while pre-monsoon, post-monsoon and winter rainfall increased at the national scale. Rainfall in June, July and September decreased, whereas in August it increased, at the national scale. The total annual and monsoon precipitation variations in the north western Himalaya (Bhutiyani et al., 2010) for the period 1866-2006 have shown decreasing trend. Dimri and Kumar (2008) and Dimri and Dash (2012) also found decreasing trend of precipitation over the western Himalaya whereas Shafiq et al., reported decreasing trend in precipitation data during 1980-2014 in Kashmir valley.

In conclusion, the results obtained from the Sirmaur district show that maximum temperature as well as minimum temperature has shown increase in every season. Winter temperature showed highest increase. Maximum temperature increased in all the months and increase in February was maximum in all the months over base line (1984-90). Minimum temperature showed an increasing as well as decreasing trend. Maximum increase in minimum temperature was observed in August over BL. Maximum decrease was recorded in summer rainfall. Maximum reduction in mean rainfall was recorded in July in 2001-10 over the baseline. An increase in total monthly rainfall over baseline was observed except May, July and December. Maximum increase in total rainfall was recorded in September while maximum reduction was in December. Mean annual rainfall followed a declining trend, while total annual rainfall increased over BL. More longterm observations and regional climate modelling studies are required over the study area in order to establish a robust relationship between climate change and its regional impacts.

\section{References}

Azadi, M., Mohanty, U.C., Madan, O.P. and Padmanabhamurty, B. (2002). Prediction of precipitation associated with a western disturbance using a high-resolution regional model: role of parameterisation of physical processes. Meteorological Applications, 9(3): 317-326.

Bhutiyani, M.R., Kale, V.S. and Pawar, N.J. (2010).Climate change and the precipitation variations in the northwestern Himalaya: 1866-2006. International Journal of Climatology, 30: 535-548.

Bhutiyani, M.R., Kale, V.S. and Pawar, N.J. (2007). Long-term trends in maximum, minimum and mean annual air temperatures across the Northwestern Himalaya during the twentieth century. Climatic Change, 85(1-2):159-177.

Chaudhary, A. and Abhyankar, V.P. (1979). Does precipitation pattern foretell Gujarat climate becoming arid. Mausam, 30:85-90.

Das, M.R., Mukhopadhyay, R.K., Dandekar, M.M. andKshirsagar, S.R. (2002). Premonsoon western disturbance in relation to monsoon rainfall, its advancement over NW India and their 
trends. Current Science, 82(11): 13201321.

Dash, S.K. and Hunt, J.C.R. (2007). Variability of climate change in India. Current Science, 93(6):782-788.

Dash, S.K., Jenamani, R.K., Kalsi, S.R. and Panda, S.K. (2007). Some evidence of climate change in twentieth-century India. Climatic Change. 85:299-321.

Dimri, A.P. (2008). Diagnostic studies of an active Western Disturbance over Western Himalaya. Mausam, 59(2):227-246.

Dimri, A.P. andGanju, A. (2007). Wintertime seasonal scale simulation over western Himalaya using RegCM3. Pure and Applied Geophysics, 164(8-9):17331746.

Dimri,A.P. and Dash, S.K. (2012). Wintertime climatic trends in the Western Himalayas. Climatic Change, 111:775-800.

Dimri, A.P. and Kumar, A. (2008). Climatic variability of weather parameters over the western Himalayas: a case study. In: Satyawali P K and Ganju A., eds. Proceedings of the National Snow Science Workshop, 11-12 January 2008, Chandigarh, India. pp. 167-173.

Goswami, B.N., Venugopal, V., Sengupta, D., Madhusoodanam, M.S. and Xavier, P.K. (2006). Increasing trends of extreme rain events over India in a warming environment. Science, 314: 1442-1445.

Hatwar, H.R., Lal, B., Rama,R.Y.V., Sud, A.M. and Kalsi, S.R. (2001).A study of heavy snowfall over western Himalayas during winter months. In: Proceedings of the Workshop on Meso-scale Modelling for Mountain Weather Forecast and its Usefulness for Improving Avalanche Forecasting, 710 November 2001, Manali, India. pp. 43-53.

Jagannathan, P. and Parthasarathy, B. (1973).
Trends and periodicities of rainfall over India. Monthly Weather Review, 101: 371-375.

Kalsi, S.R. (1980). On some aspects of interaction between middle latitude westerlies and monsoon circulation. Mausam, 38(2):305-308.

Khan, T.M.A., Singh, O.P. and Sazedur, R.M.D. (2000). Recent sea level and sea surface temperature trends along the Bangladesh coast in relation to the frequency of intense cyclones. Marine Geodesy, 23:103-116.

Koteswaram, P. andAlvi, S.M.A. (1969). Secular trends and periodicities in rainfall at west coast stations in India. Current Science, 38:229-231.

Kumar, V. and Jain, S.K. (2009). Trends in seasonal and annual rainfall and rainy days in Kashmir valley in the last century. Quaternary International, 10:1016.

Kumar, V., Jain, S.K. and Singh, Y. (2010). Analysis of long-term rainfall trends in India. Hydrological Sciences Journal, 55(4):484-496.

Kumar, V., Singh, P. andJain, S.K. (2005). Rainfall trends over Himachal Pradesh, Western Himalaya, India. In: Development of Hydro Power Projects - A Prospective Challenge. Conference. Shimla, 20-22 April, 2005.

Kothawale, D.R. and Kumar, K.R. (2005). On the recent changes in surface temperature trends over India. Geophysical Research Letter,32(18): L18714.

Kripalani, R.H., Kulkarni, A. and Sabade, S.S. (2003).Western Himalayan snow cover and Indian monsoon rainfall: are examination with INSAT and NCEP/NCAR data. Theoretical and Applied Climatology, 74 (1-2):1-18.

Lal, M. (2001). Climatic change implications for India's water 
resources. Journal of Indian Water Resources Society, 21:101-119.

Lal, M. (2003). Global climate change: India's monsoon and its variability. Journal of Environmental Studies and Policy, 6:1-34.

Min, S.K., Kwon, W.T., Park, E.H. and Choi, Y. (2003). Spatial and temporal comparisons of droughts over Korea with East Asia. International Journal of Climatology, 23:223-233.

Mirza, M.Q. (2002). Global Warming and changes in the probability of occurrence of floods in Bangladesh and implications. Global Environmental Change, 12:127-138.

Mooley, D.A. and Parthasarthy, B. (1984). Fluctuations of all India summer monsoon rainfall during 1871-1978. Climatic Change, 6: 287-301.

Pisharoty, P. andDesai, B.N. (1956). Western disturbances and Indian weather. Indian Journal of Meteorology and Geophysics, 7:333-338.

Raghavendra, V.K. (1974). Trends and periodicities of rainfall in sub-divisions of Maharashtra state. Indian Journal of Meteorology and Geophysics, 25:197210.

Rao, Y.P. and Srinivasan, V. (1969). Forecasting Manual, Part II Discussion of typical synoptic weather situation: winter western disturbances and their associated features. India Meteorological Department. FMU Report No. III-1.

Sarker, R.P. and Thapliyal, V. (1988). Climate change and variability. Mausam, 39:127-138.

Shafiq, M.U., Rasool, R., Ahmed, P. and Dimri, A.P. (2018). Temperature and Precipitation trends in Kashmir valley, North Western Himalayas. Theoretical and Applied Climatology, 135:293-304.

Shekhar, M.S., Chand, H., Kumar, S., Srinivasan, K. andGanju, A. (2010). Climate-change studies in the western Himalaya. Research and Development Centre, Snow and Avalanche Study Establishment (SASE). Annals of Glaciology, 51(54):105-112.

Shrestha, A.B., Wake, C.P., Dibb, J.E. and Mayewski, P.A. (2000). Precipitation fluctuations in the Nepal Himalaya and its vicinity and relationship with some largescale climatological parameters. International Journal of Climatology, 20: 317-327.

Thapliyal, V. and Kulshreshtha, S.M.(1991). Climate changes and trends over India. Mausam, 42: 333-338.

\section{How to cite this article:}

Reena Joshi and Verma, K. S. 2020. Understanding the Effect of Climate Change on Temperature and Precipitation in Sirmaur District of Himachal Pradesh. Int.J.Curr.Microbiol.App.Sci. 9(10): 918-928. doi: https://doi.org/10.20546/ijcmas.2020.910.110 